DEVELOPING ENGLISH WRITING MATERIALS IN NARRATIVE TEXT FOR THE EIGHTH GRADE STUDENTS OF JUNIOR HIGH SCHOOL

\begin{abstract}
AN ARTICLE
Submitted in Partial Fulfillment of the Requirement for the Degree of Sarjana Pendidikan
\end{abstract}

By

ROYANTI RAJAGUKGUK

Registration Number 2133321047

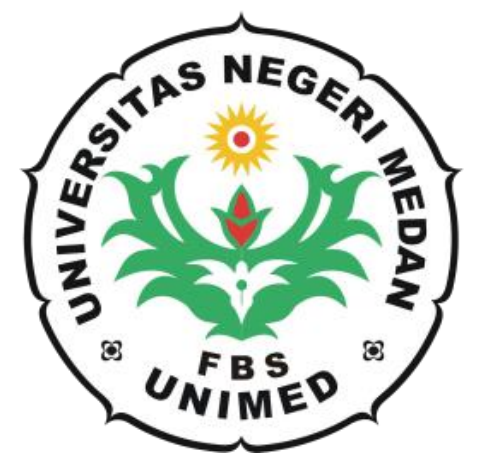

ENGLISH AND LITERATURE DEPARTMENT

FACULTY OF LANGUAGES AND ARTS

STATE UNIVERSITY OF MEDAN

2018 


\title{
ARTIKEL
}

\section{DEVELOPING ENGLISH WRITING MATERIALS \\ IN NARRATIVE TEXT FOR THE EIGHTH GRADE STUDENTS OF JUNIOR HIGH SCHOOL}

\author{
Disusun dan Diajukan oleh: \\ Royanti Rajagukguk \\ NIM. 2133321047
}

Telah diverifikasi dan dinyatakan memenuhi syarat untuk diunggah pada jurnal online

Medan, $\quad$ Mei 2018

\section{Menyetujui}

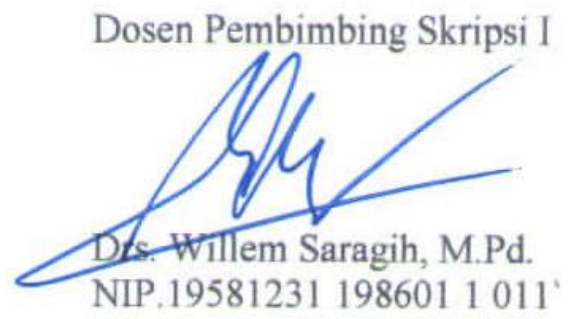

Dosen Pembimbing Skripsi II

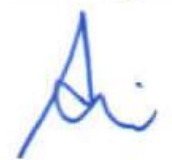

Anggraini T. Saragih, S.Pd., M.Hum.

NIP. 198011112008122003

Ka. Program Studi

Pendidikan Bahasa Inggris

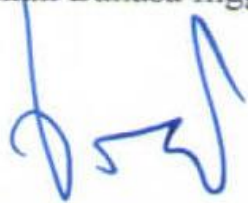

Nora Ronita Dewi, S.Pd., S.S., M.Hum.

NIP. 198005522008122003 


\title{
DEVELOPING ENGLISH WRITING MATERIALS IN NARRATIVE TEXT FOR THE EIGHTH GRADE STUDENTS OF JUNIOR HIGH SCHOOL
}

\author{
* Royanti Rajagukguk \\ ** Willem Saragih \\ ** Anggraini Thesisia Saragih
}

\begin{abstract}
Rajagukguk, Royanti. Registration Number : 2133321047 Developing English Writing Materials in Narrative Text for the Eighth Grade Students of Junior High School. A Thesis, English and Literature Department, Faculty of Languages and Arts, State University of Medan, 2018.

This research aims to develop the English writing materials in Narrative text for the Eighth Grade Students of Junior High School by using picture series. This study was conducted using R \& D method of Borg \& Gall (2003). The research took place in SMP HKBP Pardamean Medan. The sample was the Eighth Grade Students that consisted of 29 students. The evaluators of the developed materials were two experts namely an English lecturer and an English teacher. There were some instruments that were applied in this study namely observation, questionnaire and interview. The finding of the study was the suitable English writing materials in Narrative text based on the students' needs and level in SMP HKBP Pardamean Medan. The developed writing materials then were validated by the experts and it got 4,20 based on the highest interval of numerical scale was 5,00 . In the form of percentage, it got $84 \%$ so it was categorized as "very good". Therefore, it can be concluded that the developed English writing materials in Narrative text are appropriate to students' needs and level and interesting for them. Automatically, it can be used for the Eighth Grade Students of Junior High School in teaching-learning activity in the classroom to increase the students' ability in writing Narrative text and motivate them in learning writing especially in Narrative Text.
\end{abstract}

Keywords: Writing, Narrative text, Picture series, Research and Development $(R \& D)$.

\footnotetext{
*Graduate

***ecturer
} 


\section{INTRODUCTION}

\section{Background of the Study}

In learning English, there are four major skills that should be mastered by students. They are; listening, reading, speaking, and writing. In this study the writer focuses on writing skill only. Among the four skills of learning English, writing is considered as the most difficult skill to learn, as Nunan (1999:271) states writing is something that most native speakers never master. In learning writing, students have to learn how to put their own ideas, develop their ideas, arrange their ideas into good sentences, make their writing cohesion and coherence, etc. Therefore, being good in writing is not easy. It needs many exercises.

The importance role of writing in English language teaching and learning, especially for Junior High School can be seen in the curriculum. Nowadays, the education system in Indonesia implements two curricula. They are School Based Curriculum 2006 and Curriculum 2013. In both of the curricula, the students are expected to communicate interpersonally, transactionally and functionally about themselves and their environment in their daily life. They should be able to produce short spoken and written text, too (Kemdikbud, 2016). Therefore, the students should be able to comprehend and produce not only short functional texts, such as announcement, invitation, and advertisement; but also long functional text such as descriptive, recount and narrative text. In addition, it is also stated that the objective of teaching English for Junior High School is the students 
should be able to identify social function, generic structure, and linguistic feature of the text.

Based on School Based Curriculum 2006 and Curriculum 2013, there are three types of texts that should be learnt by the Eighth Grade Students of Junior High School. They are descriptive text, recount text and narrative text. From the three of texts, the writer just focuses on Narrative text. There is a belief that it is a genre that students 'pick up' and write 'naturally' (Knapp and Watkins, 2005:220).

The students should learn about writing Narrative text can be seen from one basic of basic competences of English subject stated in syllabus:

12.2. Mengungkap kan makna dan langkah retorika dalam esei pendek sederhana dengan menggunakan ragam bahasa tulis secara akurat, lancar dan berterima untuk berinteraksi dengan lingkungan sekitar berbentuk recount dan narrative.

In addition, the type of Narrative texts that the students should learn namely fable. Fable becomes a choice because the Eighth Grade Students of Junior High School are categorized as the beginners in writing so it is better if the story that they write or listen is about fable which has a moral lesson to build their good character. It is also supported by the basic competences of English subject stated in syllabus in curriculum 2013 :

\subsection{Menyusun teks naratif berbentuk fable, pendek dan sederhana.}

In English teaching, in addition to media, technique and method, materials are also important one for students. Materials are one of the most important influences on what is going on in the classroom. Materials can also improve students' writing ability. The use of suitable materials will help students to learn 
writing in a good way. In teaching-learning process, teachers have to choose the appropriate materials for students to encourage the students in improving the students' ability in writing. However, it is often found that materials are not suitable to the students' need or level and not interesting for students.

Based on the writer's observation in SMP HKBP Pardamean Medan, it was found that the writing materials in the available textbook were not suitable to students' need and level and also not interesting for them. it can be said that the materials are too difficult for students because the writing materials in textbook just provide a picture without keywords then give an order statement to students to write a narrative story which is suitable to the picture without giving the sequence pictures (Picture Series). Of course, it made them frustrated, moreover if they are not familiar with the story.

Furthermore, based on English Basic Competences, the Eighth Grade Students of Junior High School should just focused on story about fable (4.18. Menyusun teks naratif berbentuk fable, pendek dan sederhana) but the existing materials provided some practices to students about folklore that should be learnt by students grade IX of Junior High School (4.12. Menyusun teks naratif berbentuk cerita rakyat, pendek dan sederhana).

By using the existing materials which just provided one picture, the students felt difficult in writing a text without picture series. They have no idea to write. The difficulties can be seen from the works of the students. Of the 29 students in a classroom, the researcher concluded that : only $75 \%$ of them could make orientation, $45 \%$ for complication, $0 \%$ for resolution. 
In addition to the data above, it also was found that the students also felt difficult to write the story in chronological order without picture series.

Therefore, it is concluded that the students feel difficult in writing narrative text without picture series moreover if they are not familiar with the story. That is the reason why the writer wants to develop the writing materials from the existing one. The writer will develop the writing materials by giving picture series. The writer will search and find out interesting picture series from some sources such as from internet and other English textbooks. Picture Series will help students to think and explore about the topic and its details based on the pictures which are provided. The picture series in the textbook can not only facilitate $\&$ help students to get an idea in creating a narrative text but also it can create a fun atmosphere in teaching and learning process. It can make students feel interested and happy in learning English especially in writing narrative text. Finally the students can write narrative text effectively.

\section{REVIEW OF LITERATURE}

Langan (2008:15) says that writing is a way to communicate with others. Through writing, the author writes her/his ideas or thought into a text. Writing also is defined as the most difficult skill than the other skills because students have to write about what they think in their mind and state it on a paper in the correct procedure. Therefore being good in writing needs many exercise. According to Pardiyono (2007 : 2), there are eleven types of genre of text and one of them is Narrative text. Narrative text is a text that discussed in this study. 
Narrative is a genre that students 'pick up' and write 'naturally' (Knapp and Watkins $2005: 220$ ). There are some purposes of Narrative text such as to entertain or amuse the readers, convey moral lesson and change social opinions and attitudes. While, the generic structures of narrative text namely; orientation, complication and resolution.

In English teaching and learning process, material is one of the important components. It can facilitate the teachers in the teaching and learning process. O'Neill (1990) emphasizes that materials help learning and teaching process. The use of suitable materials to the students' need and level is so important. Therefore the materials evaluation is important to do in order to measure the quality of learning materials, whether it can achieve the goal of learning or not (Tomlinson, 1998). If the materials are not suitable to the students' need and level, then the material should be developed.

The researcher developed the writing materials by using picture series. Wright (1989) argues that picture series are pictures which show some actions or events in a chronological order. In Hesthi (2016), there are some advantages of the use of picture series, such as helping the students to generate ideas, drawing students' attention out to be involved in writing process and increasing students' vocabulary.

There are some relevant studies that will support this research.

First, The Use of Picture Series on Writing Narrative Text Skill ; an Experimental Study at Grade X Students of MAN 1 Mataram in Academic Year 2016/2017 by Juniarti. Second, R \& D Research was conducted by Satriani (2012). Futhermore, 
Desitawardhani (2014) also conducted action research by using picture series to improve students' writing ability. All those studies revealed that picture series were useful to improve students writing ability.

\section{RESEARCH METHODOLOGY}

Research Design

The objective of this research was to develop the suitable English writing materials in Narrative text for the Eighth Grade Students of Junior High School. These materials were developed based on the students' needs. Research and Development (R\&D) model of Borg and Gall (2003) was conducted in this research. Borg and Gall (2003: 569) state that "Educational R\&D is an industrybased development model in which the findings of research are used to design new products and procedures.

\section{Research Subject}

The Subject of this study was the Eighth Grade Students of Junior High School at SMP HKBP Pardamean Medan. The location is in Jl. Taduan No.94 Medan .The class consisted of 29 students.

\section{Instruments of Data Collection}

The data of the research was collected by doing observation, questionnaire and interview. 


\section{Techniques of Data Analysis}

Analyzing the data was conducted by these following steps:

1. Analyzing the existing materials and students' need. The data is taken from the observation, questionnaire and interview

2. Matching the existing material with students' need

3. Developing the suitable English writing materials in Narrative text based on the students' need and level.

\section{DATA ANALYSIS}

1. Gathering information and data: The data were collected by using some instruments namely: observation, questionnaire and interview.

The data which were observed by the researcher namely : curriculum, sylla bus and the existing materials. The questionnaire was administrated to students to get the related data about students' needs, difficulties and problems, students' opinion about existing materials and students' expectation about the materials. The interview was administered to English teachers to find out the detail information about the existing materials and students' difficulties and problems in writing Narrative text and also the teacher's ideas about the suitable English writing materials.

2. Need analysis :

a. Existing materials : The textbook which was used by the students in grade VIII entitled English in Focus for Grade VIII Junior High School 
(SMP/MTs). It was written by Wardiman, Artono, Masduki B. dan M. Sukirman and was published by Book Center of the Ministry of National Education in 2008.

b. Questionnaire Analysis : The questionnaire was in the form of multiple choices of twenty questions. It was divided into 3 categories namely: necessities; lacks; and want (Hutchinson and Waters, 1987:54).

c. Interview Analysis: There were 5 questions that the researcher gave to the English teacher to support the questionnaire in order to get more detail information about the students' problems and needs.

Based on the data that were taken from questionnaire and interview analyses, the researcher found that the writing materials in the textbook were not suitable to students' needs \& level and not interesting for them. The textbook provided the text that the students should not learn. Actually, they need to learn the topic about fable but the textbook provided text about folklore that should be learnt by the Ninth Grade Students of Junior High school. They also need picture series to help them in finding the ideas to write a narrative story.

3. Developing Materials: The new writing materials were developed by using picture series. Picture series consist of sequence pictures that tell how something is accomplished or how something happened. By using picture series, learning process in the classroom will be more effective.

4. Validating by experts: The new writing materials were evaluated or validated by two experts. Firslyt, Mr. Indra Hartoyo, S.Pd, M.Hum as a 
lecturer at English and Literature Department in the State University of Medan and secondly, Mrs. Susi Panggabean, S.S. as an English teacher at SMP HKBP Pardamean Medan. There were four aspects that were evaluated by the experts. Those aspects were: linguistic dimension, process, product and content and layout.

5. Revising writing materials: In this step, the writing Narrative text materials which had been developed by the researcher were revised based on the experts' revisions or suggestions to be improved and so it produced better materials for students. Some suggesstions of the experts are about the cover, the instruction, the size of the picture and gave a grammar exercise.

\section{CONCLUSION AND SUGGESTION}

The Conclusion

After analyzing the data, the conclusion are drawn as the following:

\section{A. Conclusion}

After analyzing the data, the conclusions are drawn as the following :

Based on the research that had been done for the Eighth Grade Students of Junior High School in SMP Pardamean Medan, it can be concluded that the writing materials on the English textbook were not suitable to the students' need and level. The first, the writing materials were not suitable to the students' need. The Eighth Grade Students should learn about fable but the existing materials 
provided the story about folklore. The second, it could be said that the existing materials were too difficult for students because the writing materials in textbook just provide a picture without keywords then give an order statement to students to write a narrative story which is suitable to that picture without giving the sequence pictures (Picture Series). As the result, the students felt frustrated because they have no ideas to write moreover if they are not familiar with the story. Therefore, the existing materials should be developed so that the students have the suitable English writing materials which will support their learning activity and increase their knowledge in writing Narrative text.

\section{The Suggestions}

In relation to the conclusion, the suggestions are as the following:

1. Teacher

The English teachers are suggested to use materials that meet the students' needs and level. The teachers also are suggested to apply picture series. It can help the students in finding the ideas and also attract the students' attention to write.

\section{Students}

Students can find the materials that meet their need and level from some sources like internet or the other English textbooks if the existing materials are not suitable to their need and level. 


\section{School Parties}

School Parties also should find the books which are match to the students' needs and level and provide a number of references of English textbooks.

4. For other researchers

It is expected that the other researchers who have the same interest in this field could make more interesting materials.

\section{REFERENCES}

Desitawardhani, N. 2014. Improving Students' Skills of Writing Explanation Texts through Picture Series for the Grade XII Students of SMA Negeri 2 Sleman in the Academic Year of 2013/2014. Thesis. Yogyakarta: State University of Yogyakarta

Gall, Meredith D., Gall, Joyce P. \& Borg Walter. 2003. Educational Research: An Introduction. Boston : Pearson Education, Inc.

Hesthi. 2016. The Role of Picture series in improving students Writing Ability. Malang: State University of Malang.

Juniarti. 2007. The Use of Picture Series on Writing Narrative Text Skill ; an Experimental Study at Grade X Students of MAN 1 Mataram. Mataram: University of Mataram.

Kemdikbud. 2016. Peraturan Menteri Pendidikan dan Kebudayaan Republik Indonesia Nomor 21 Tahun 2016 tentang Standar Isi Pendidikan Dasar dan Menengah. Jakarta: Kementerian Pendidikan dan Kebudayaan.

Knapp\&Watkins, M.2005. Genre, Text, Grammar: Technologies for Teaching and Assessing Writing. Australia: University of South Wales Press. 
Langan, J.2008.College writing Skill with Readings. Seven Edition. New York: McGraw-hill Companies.

Nunan. 1999. Second Language Teaching \& Learning. Boston: Heinle \& Heinle publishers.

O'Neill, R.1990. Why use textbooks? In R. Rossner and R. Bolitho, (Eds.), Currents in language teaching. Oxford: Oxford University Press.

Pardiyono. 2007. Pasti bisa! Teaching Genre-Based Writing: Metode Mengajar Berbasis Genre Secara Efektif. Yogyakarta: ANDI.

Satriani. 2012. Developing writing materials by using a genre -based approach for eighth grade students of SMPN 4 Playen Gunungkidul. Thesis. Yogyakarta:State University of Yogyakarta.

Tomlinson, B. 1998.Materials Development in Language Teaching. Cambridge: Cambridge University Pers.

Wright, A. 1989. Picture for Language Learning. New York: Cambridge University Press. 